\title{
The current status of knowledge on Lycidae Laporte, 1836 from Brazil (Insecta: Coleoptera)
}

\author{
Elynton Alves do Nascimento
}

Universidade Estadual do Centro-Oeste, Departamento de Engenharia Ambiental. PR 153, Km 7, Riozinho,. CEP 84500-000. Irati, PR, Brazil. E-mail: elynton@yahoo.com.

\begin{abstract}
Lycids are often very aposematic toxic beetles, and are considered models in mimicry systems. They are cosmopolitan, with the highest diversity around tropical regions, however the knowledge of the South American lycids is yet relatively poor. Here I present an overview of the Brazilian lycids including a complete list of species and updated occurrence data.
\end{abstract}

\section{INTRODUCTION}

The lycids are soft-bodied beetles, often aposematically colored, presenting high levels of toxins, largely known to act as center models in mimetic rings (Marshall and Poulton 1902; Shelford 1902; Guenther 1931; Darlington 1938; Linsley et al. 1961; Moore and Brown 1981). The family Lycidae is a member of Elateriformia series, placed in the Elateroidea superfamily, together with other soft-bodied families like Cantharidae, Lampyridae, Phengodidae, Telegeusidae, as well as hard-bodied Elateridae, Eucnemidae, Throscidae and others (Lawrence and Newton 1995; Lawrence et al. 1999; Beutel and Leschen 2005). Lycids are externally similar to cantharids and lampyrids, but can be generally distinguished by the head not entirely covered by the pronotum (a character that differentiates them from higher lampyrids) and by having 3 to 4 strong costae on each elytron, usually with reticulate cells (costae are lacking in Cantharidae and at least reticulate cells are lacking in Lampyridae, since most taxa have some costae). Lycids also differ from fireflies and soldier beetles by presenting long trochanters with insertion of femur mostly set off or sometimes slightly oblique (mostly oblique in lampyrids and strongly oblique in cantharids), moreover their midcoxae are distinctly separated, while continuous or almost continuous in Cantharidae and Lampyridae.

Lycids, also known as net-winged beetles, are cosmopolitan and most diverse in tropical regions (Wallace 1867; Kleine 1933; Blackwelder 1945). The taxonomical and distributional knowledge is reasonable in North America and some regions of Central America, well established in Europe and many Asiatic regions, but relatively poor in South America (e.g. Leng and Mutchler 1922; Darlington 1938; Green 1949; Bocak and Bocakova 1990, 1999; Bocak 1998; Zaragoza-Caballero 1999; Bocakova 2001, 2003; Kazantsev 2004, 2005).

This family is comprised of about 110 genera and over 4000 described species (Kleine 1933; Blackwelder 1945; Bocakova 2001, 2003; Bocak and Bocakova 2008). According to former works, some authors indicated the presence of 40 genera and 800 species in the Neotropical region, and about 150 species distributed in 22 genera in
Brazil (Kleine 1933; Blackwelder 1945; Costa et al. 1988; Costa 2000).

Although the majority of Brazilian lycid species was described by foreign taxonomists up to 1949 (Table 1), there is a recent interest emerging in national researchers to study little known elateroids in the country. Former researchers usually received specimens from Brazil and other South American countries and often the collection site was not precise, or even non-existent, labeled only as "Brazil", "Brasilia" or "South America". Brazilian lycid fauna has never been subject of direct survey, there are precious, but little accessible information about geographic distribution of species and even genera, available only in some descriptive works or short communications (e.g. Bourgeois 1886, 1905).

Therefore, the data on lycids from Brazil were accessed strictly from species described before the first half of $20^{\text {th }}$ century. Bocakova $(2001,2003)$ redescribed some Brazilian species, however, after Pic (1949) no single lycid species was described from Brazil until the work of Nascimento and Bocakova (2009). Herein I present updated data on the Brazilian lycids, especially new records for the country.

\section{MATERIALS AND Methods}

The data on Brazilian lycids was obtained from literature (Kleine 1933, 1942, Blackwelder 1945, Nascimento and Bocakova 2009, 2010a, b) and based on field work, mainly from Atlantic Forest remnants in São Paulo State and examination of the material held in the collections of Museu de Zoologia da Universidade de São Paulo, São Paulo, Brazil (MZSP); Coleção Entomológica Pe. Jesus Santiago Moure - Departamento de Zoologia da Universidade Federal do Paraná, Curitiba, Brazil (DZUP); Muséum National d'Histoire Naturelle, Paris, France (MNHN); British Museum of Natural History, London, United Kingdom (BMNH) and from Instituto Nacional de Pesquisas da Amazônia (INPA), Manaus, Brazil.

\section{Results AND Discussion}

Bocak and Bocakova (1990) established the first higher classification of Lycidae family, thereafter some 
changes were made and are summarized in Bocak and Bocakova (2008), that established a new classification, considering morphological and molecular data, wherein six subfamilies were recognized, being one of the main changes in Calochrominae Lacordaire, 1857 and Erotinae Leconte, 1881, both lowered to the tribal status within Lycinae Laporte, 1836. Even considering some changes proposed by R.S. Miller (unpublished data) and Kazantsev and Zaitsev (2008), all lycid taxa known to occur in Brazil belong to Lycinae, the largest of the subfamilies, representing $93 \%$ of all the described species of the world (Bocak and Bocakova 2008).

Among the tribes that occur in Brazil, Calopterini Green, 1949 is the richest, with 14 genera, followed by Eurrhacini Bocakova, 2006 and Platerodini Kleine, 1928 with 5 genera; and Leptolycini Leng and Mutchler, 1922, with three genera; and Calochromini Lacordaire, 1857 and Lycini Laporte, 1836 with a single genus (Pic 1929; Kleine 1933; Blackwelder 1945; Nascimento and Bocakova 2009, 2012; E.A. Nascimento unpublished data) (see Table 1).

TABLE 1. List of genera and species present in Brazil. **: undescribed or unidentified species; (?): doubtful record.

\begin{tabular}{|c|c|}
\hline TAXON & $\begin{array}{c}\text { NUMBER OF } \\
\text { BRAZILIAN SPECIES }\end{array}$ \\
\hline \multicolumn{2}{|l|}{ Subfamily LYCINAE Laporte, 1836} \\
\hline \multicolumn{2}{|l|}{ Tribe Calochromini Lacordaire, 1857} \\
\hline Macrolygistopterus Pic, 1929 & 7 \\
\hline \multicolumn{2}{|l|}{ bilineatus (Pic, 1923) } \\
\hline \multicolumn{2}{|l|}{ elegans Bourgeois, 1880} \\
\hline \multicolumn{2}{|l|}{ germaini Pic, 1930} \\
\hline \multicolumn{2}{|l|}{ gounellei Bourgeois, 1886} \\
\hline \multicolumn{2}{|l|}{ goyasensis Pic, 1923} \\
\hline \multicolumn{2}{|l|}{ quadricostatus (Buquet, 1842) } \\
\hline \multicolumn{2}{|l|}{ testaceirostris Pic, 1930} \\
\hline \multicolumn{2}{|l|}{ Tribe Calopterini Green, 1949} \\
\hline \multicolumn{2}{|l|}{ Subtribe Acroleptina Bocakova, 2005} \\
\hline Acroleptus Bourgeois, 1886 & 1 \\
\hline \multicolumn{2}{|l|}{ chevrolati Bourgeois, 1886} \\
\hline Brasilycus Nascimento and Bocakova, 2010 & 2 \\
\hline \multicolumn{2}{|l|}{ capixabus Nascimento and Bocakova, 2010} \\
\hline \multicolumn{2}{|l|}{ rondonensis Nascimento and Bocakova, 2010} \\
\hline Ceratopriomorphus Pic, 1922 & 1 \\
\hline \multicolumn{2}{|l|}{ humeralis Pic, 1922} \\
\hline Cyrtopteron Bourgeois, 1905 & 2 \\
\hline \multicolumn{2}{|l|}{ atricorne Pic, 1922} \\
\hline \multicolumn{2}{|l|}{ reverens Kleine, 1942} \\
\hline Falsocaenia Pic, 1922 & 3 \\
\hline \multicolumn{2}{|l|}{ decipiens (Gorham, 1884) } \\
\hline \multicolumn{2}{|l|}{ incognitus Kleine, 1942} \\
\hline \multicolumn{2}{|l|}{ paranana (Pic, 1922) } \\
\hline Lycinella Gorham, 1884 & $-* *$ \\
\hline Lycomorphon Pic, 1922 & 2 \\
\hline \multicolumn{2}{|l|}{ amazonicum Nascimento and Bocakova, 2009} \\
\hline \multicolumn{2}{|l|}{ brasiliense Nascimento and Bocakova, 2009} \\
\hline Mesopteron Bourgeois, 1905 & 11 \\
\hline \multicolumn{2}{|l|}{ amparosum Pic, 1938} \\
\hline angulicolle (Lucas, 1857) & \\
\hline filiforme (Lucas, 1857) & \\
\hline flavocostatum (Taschenberg, 1874) & \\
\hline fossulatum (Lucas, 1857) & \\
\hline gounellei Pic, 1931 & \\
\hline notaticolle Pic, 1922 & \\
\hline orosicum Pic, 1933 & \\
\hline pauli Pic, 1931 & \\
\hline subnitidum Pic, 1931 & \\
\hline subopacum Pic, 1931 & \\
\hline Subtribe Calopterina Green, 1949 & \\
\hline Caenia Newmann, 1838 & 1 \\
\hline diversipennis Pic, 1923 & \\
\hline Calopteron Castelnau, 1838 & 39 \\
\hline affine Lucas, 1857 & \\
\hline angustalisi Pic, 1933 & \\
\hline anxium Bourgeois, 1879 & \\
\hline apicale (Guérin-Méneville, 1838) & \\
\hline
\end{tabular}


Table 1. Continued.

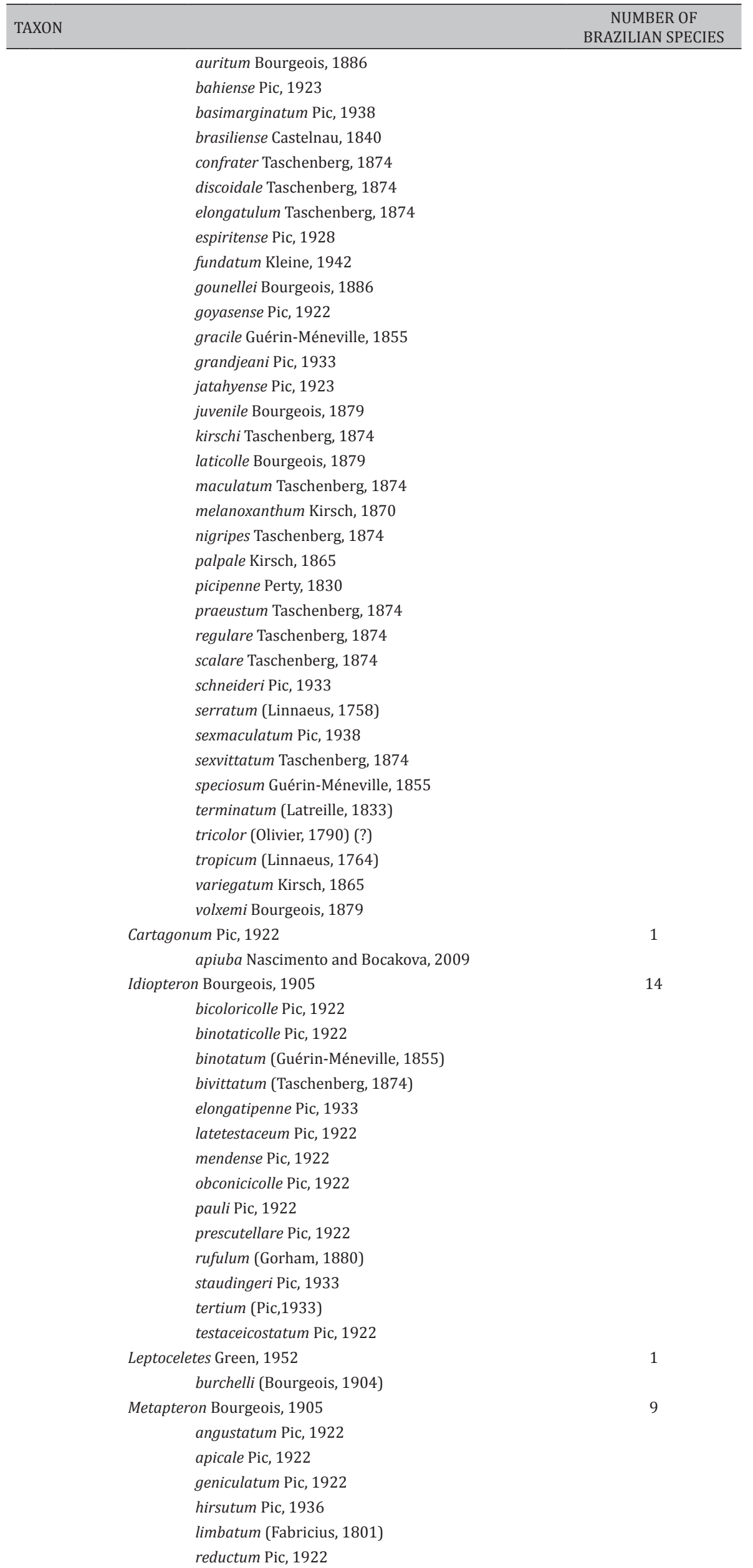


TABLE 1. Continued.

$\begin{array}{cc}\text { TAXON } & \text { NUMBER OF } \\ \text { BRAZILIAN SPECIES }\end{array}$

signaticolle Pic, 1922

suturale (Latreille, 1833)

xanthomelas (Lucas, 1857)

Tribe Eurrhacini Bocakova, 2005

Calocladon Gorham, 188

Emplectus Erichson, 1847

abundans (Taschenberg, 1874)

apicalis Pic, 1923

foveolatus (Pic, 1922)

hickeri Pic, 1928

minarum Bourgeois, 1886

multipunctatus (Pic, 1922)

piceus Pic, 1923

scalaripennis Bourgeois, 1886

stipatus Bourgeois, 1886

subtilis Kleine, 1943

Eurrhacus Waterhouse, 1879

Linoptes Gorham, 1884

amazonicus Pic, 1923

atripennis Pic, 1932

Lycoplateros Pic, 1922

Haplobothris Bourgeois, 1879

apicicornis Pic, 1931 (?)

baeri Pic, 1930

basipennis Pic, 1938

elongata Pic, 1922

gounellei Pic, 1922

hahneli Pic, 1938

humeralis Bourgeois, 1879

infasciata Pic, 1938

mediofasciata Pic, 1938

melzeri Pic, 1935

nigroapicalis Pic, 1935

nigronotata Pic, 1912

pumila Bourgeois, 1879

robusta Pic, 1922

scapularis Bourgeois, 1879

setosella Bourgeois, 1886

testacea Pic, 1930

Tribe Leptolycini Leng and Mutchler, 1922

Pseudacrolepteus Pic, 1911

obscuricolor Pic, 1911

Flabellocaenia Pic, 1929

bourgeoisi Pic, 1931

Neolyrium Kazantsev, 2005

Tribe Lycini Laporte, 1836

Lycus Fabricius, 1787

Tribe Platerodini Kleine, 1929

Cavoplateros Pic, 1913

spinipes Pic, 1913

Falsocalleros Pic, 1933

Picomicrolycus Özdikmen, 2009

ireneae Nascimento and Bocakova, 2012

Plateros Bourgeois, 1879

angustior Pic, 1925

apicalis (Germar, 1824)

armitagei (Pic, 1934)

bang-haasi (Pic, 1931)

basalis (Pic, 1939)

batesi (Pic, 1922) 


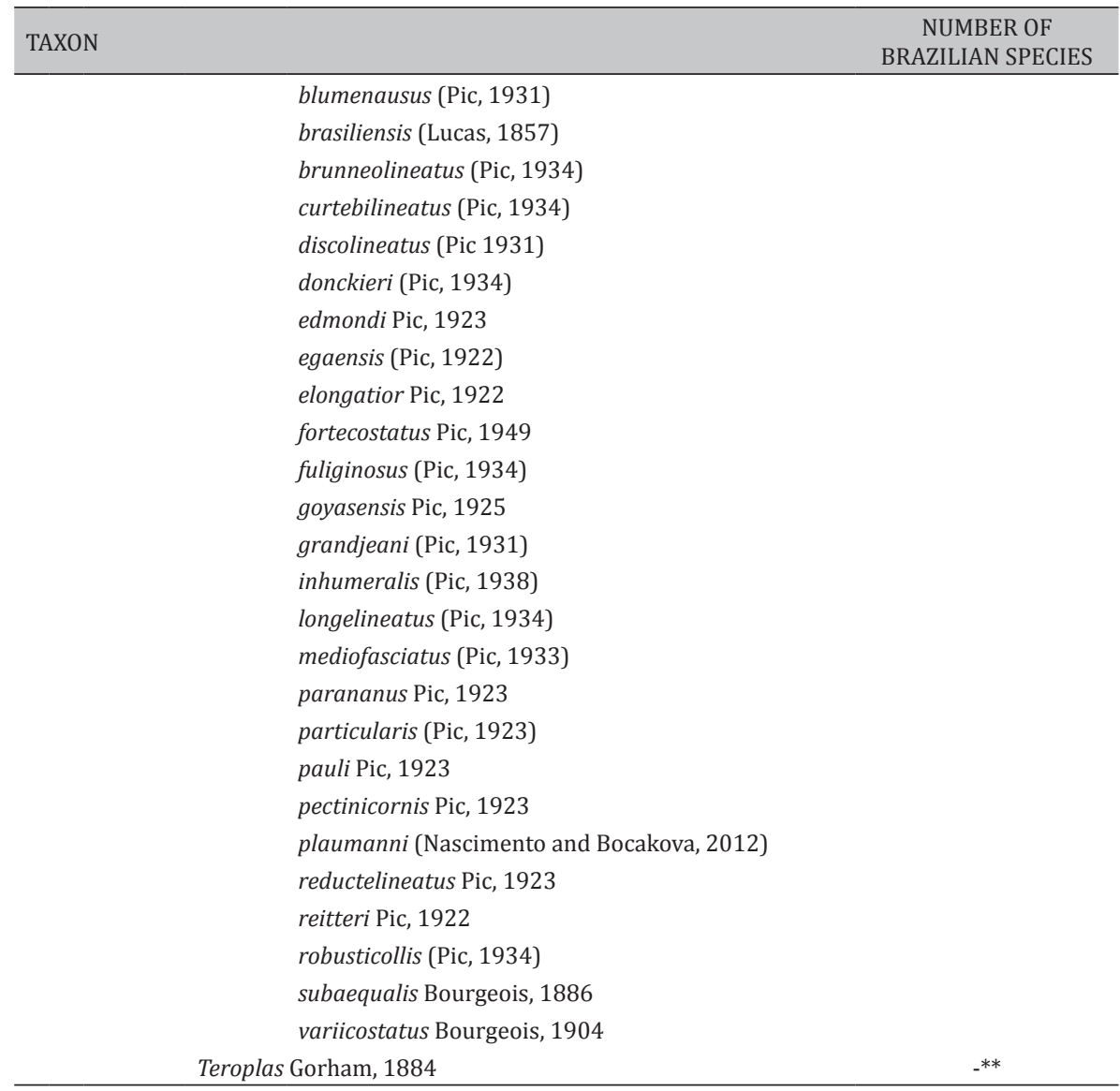

Considering the genera placed as incertae sedis by Bocakova (2003) as non-calopterin (see also Kazantsev and Zaitsev 2008), all Calopterini are known to occur in Brazil, including Lycinella Gorham, 1884, recently reported from São Paulo State (E.A. Nascimento, unpublished data). The tribe Platerodini has a wide geographical distribution (Bocak and Bocakova 1990, 2008), but some genera were considered to be exclusive to Central and North America (Bocakova 2001; Kazantsev 2005). It should be stressed here that some of these genera in fact occur in Brazil, namely Falsocalleros Pic, 1933, Picomicrolycus (Pic, 1922) and Teroplas Gorham, 1884 with undescribed and recently described species from São Paulo State (Nascimento and Del-Claro 2010, Nascimento and Bocakova 2012a). Recently Nascimento and Bocakova (2012b) synonymized Sculptocalleros Pic, 1949 with Plateros.

In Calochromini, Kleine (1933) and Blackwelder (1945) overlooked the act made by Pic (1929) when created the genus Macrolygistopterus Pic, 1929, transferring all American species of Lygistopterus Mulsant, 1838 to Macrolygistopterus. In this way, only Macrolygistopterus occurs in Brazil. Considering Pseudacroleptus Pic, 1911 and Flabellocaenia Pic, 1929 as members of Leptolycini, as proposed by R.S. Miller (unpublished data) and Kazantsev and Zaitsev (2008), and the recently found Neolyrium Kazantsev, 2005 from Paraná and São Paulo States (E.A. Nascimento, unpublished data), Leptolycini also occurs in Brazil. Tribe Lycini is represented by a single species of Lycus Fabricius, 1887.

According to Kleine (1933) and Blackwelder (1945), Erotini is represented by a Brazilian species of Eros
Newman, 1838, but this occurrence is controverse, since according to Bocak and Bocakova 2008, this genus occurs in the Palaeartic, Neartic and Oriental regions, and probably many species are misplaced in this genus (see Kazantsev 2004). Furthermore, considering the original description data, referring Eros melanopterus Lucas 1857 as collected in the Sarayacu mission, and according to discussions with colleagues (U.R. Martins and R. Constantin, personal communication) besides bibliographic data (Herndon 1854), I consider that this species do not occur in Brazil, but in Peru, more precisely in Ucayali region (R. Constantin, personal communication).

In Eurrhacini, Eurrhacus Waterhouse, 1879; Calocladon Gorham, 1881 and Lycoplateros Pic, 1922 were yet not registered from Brazil. Some Eurrhacus specimens from Paraná, Espírito Santo, São Paulo, Goiás and Roraima States were analized. Lycoplateros specimens were collected by the author in São Paulo State and it is now also known from Paraná, Espírito Santo, Mato Grosso, Rondônia, Pará, Roraima and Amazonas States, showing a distribution from Southern to Northern Brazil. Calocladon is known from Acre, Amazonas, Roraima, Mato Grosso and Paraná States; moreover it was recently collected by the author in São Paulo State (Southeastern Brazil). Therefore, these registers are important, since it shows a considerably occurrence extension of these previously unknown genera in Brazil, including many undescribed species.

Some new Calopterini were recently described and registered for the first time from Brazil, namely Lycomorphon Pic, 1922 (Northern and Southeastern regions) and Cartagonum Pic, 1922 (Southeastern region), increasing the 
knowledge on the geographical distribution of these taxa in the Neotropical region (Nascimento and Bocakova 2009, 2010a). Although not reported in Bocakova et al. (2012), a recent analysis of the collection from CECG showed that Falsocaenia paranana (Pic, 1922) also occur in Brazil, in Southeastern region. The genus Brasilycus Nascimento and Bocakova, 2010 and two new species from Brazil were described from Northern and Southeastern regions (Nascimento and Bocakova, 2010b). Since the females are poorly known, and sometimes descriptions are completely lacking, and due to the importance of these characters in the cladistic analyses (e.g. Bocakova 2005), I therefore stress its importance for future works dealing with lycid taxonomy and systematics.

The present data comprises a total of 31 genera and 160 described species of Lycidae occurring in Brazil (Kleine 1933; Blackwelder 1945; Pic 1929; Nascimento and Bocakova 2009, 2010a, 2010b, 2012a, 2012b, E.A. Nascimento, unpublished data). The huge gap in Brazilian lycids studies is just starting to be covered, some genera are being revised and new ones described, but there is still a lot of work ahead in Brazil, from taxonomy to ecology.

ACKNowledgments: I would like to thank M. Bocakova and G. Biffi for the valuable comments on the manuscript, to CNPq for the doctoral grant and FAPESP process n. 2010/15427-1. I am very much obliged to H.F. Mendes for the text review and English improvement. I am also thankful to colleagues for field help and for provide specimens (C.M. Polegatto, G. Biffi, V.S. Ferreira, L.S. Lecci and A.R. Calor). Special thanks are also due to the curators and staff of the above mentioned collections, C. Campaner, S.A. Casari and C.J.E. Lamas (MZSP); N.G. Ganho and L.M. Almeida (DZUP); A.L. Henriques (INPA) ; A. Thagavian and T. Deuve (MNHN) and Max Barclay (BMNH).

\section{Literature Cited}

Beutel, R.G. \& R.A.B. Leschen. 2005. 2. Classification, p. 11-16. In R. G. Beutel \& R.A.B. Leschen (eds.). Coleoptera, Beetles, Volume 1: Morphology and Systematics (Archostemata, Adephaga, Myxophaga, Polpyhaga partim), Teilband / Part 38. In N.P. Kristensen \& R.G. Beutel (eds). Handbuch der Zoologie / Handbook of Zoology, Band / Volume IV Arthropoda: Insecta. Walter de Gruyter, Berlin, XI + 567 p.

Blackwelder, R.E. 1945. Checklist of the coleopterous insects of Mexico, Central America, the West Indians and South America - Part 3. Bulletin, United States National Museum 185: 343-550.

Bocak, L. 1998. New and little known species of Conderini and Ateliini (Coleoptera: Lycidae). Acta Universitae Palackianae Olomucensis 36: 17-26.

Bocak, L. and M. Bocakova. 1990. Revision of the supergeneric classification of the family Lycidae (Coleoptera). Polskie Pismo Entomologiczne 59: 623-676.

Bocak, L. and M. Bocakova. 1999. New taxa of Lycidae from Indonesia, China and Nepal. Acta Universitae Palackianae Olomucensis 37: 4756.

Bocak, L. and M. Bocakova. 2008. Phylogeny and classification of the family Lycidae (Insecta: Coleoptera). Annales Zoologici 58: 695-720.

Bocakova, M. 2001. Revision and phylogenetic analysis of the subfamily Platerodinae (Coleoptera: Lycidae). European Journal of Entomology 98: 53-85.

Bocakova, M. 2003. Revision of the Tribe Calopterini (Coleoptera, Lycidae). Studies on Neotropical Fauna and Environment 38: 270-234.

Bocakova, M. 2005. Phylogeny and classification of the tribe Calopterini (Coleoptera, Lycidae). Insect Systematics and Evolution 35:437-447.

Bourgeois, J. 1886. Communications. Bulletin des Séances et Bulletin Bibliographique de la Société Entomologique de France (6) 6: 131132.

Bourgeois, J. 1905. Les Lycides du Muséum d'Histoire Naturelle de Paris. Annales de la Société Entomologique de France 74: 109-126.

Costa, C. 2000. Estado de conocimiento de los Coleoptera neotropicales, p. 99-114 In: F. Martin-Piera, J.J. Morrone, and A. Melic. (eds.). Hacia un proyecto CYTED para el inventario y estimación de la diversidad entomológica en Iberoamérica: PrIBES-2000. M3M: Monografías Tercer Milenio Vol. I. Zaragoza: Sociedad Entomológica Aragonesa \& Programa Iberoamericano de Ciencia y Tecnología para el Desarrollo.

Costa, C.; S.A. Vanin and S.A. Casari-Chen. 1988. Larvas de Coleoptera do Brasil. São Paulo: Museu de Zoologia, Universidade de São Paulo. 282 p.

Darlington, P.J. 1938. Experiments on mimicry in Cuba with suggestions for future study. Transactions of the Royal Entomological Society of London 87: 681-695.

Green, J.W. 1949. The Lycidae of United States and Canada: I. The Tribe Lycini (Coleoptera). Transactions of American Entomological Society 75: 53-70.

Guenther, K. 1931. A Naturalist in Brazil. Boston \& New York, Houghton Mifflin Company. 400 p.

Kazantsev, S.V. 2004. Phylogeny of the tribe Erotini (Coleoptera, Lycidae), with descriptions of new taxa. Zootaxa 496: 1-48.

Kazantsev, S.V. 2005. A review of the genera Microlycus Pic, 1922 and Teroplas Gorham, 1884 (Coleoptera: Lycidae). Russian Entomological Journal 14: 275-280.

Kazantsev, S.V. and A.A. Zaitsev. 2008. description of larval and imaginal stages of new species from the genera Pseudacroleptus Pic, 1911 and Ceratoprion Gorham, 1880 (Coleoptera: Lycidae: Leptolycini). Russian Entomological Journal 17: 283-292.

Kleine, R. 1933. Lycidae. In S. Schenkling (ed.). Coleopterorum Catalogus auspiciis et auxilio Pars 128. Berlin: W. Junk. 145 p.

Kleine, R. 1942. Neue Lyciden des äthiopischen und neotropischen Faunengebietes (Col.). Mitteilungen der Münchener Entomologische Gesellschaft 32: 149-162.

Herndon, W.L. 1854. Exploration of the Valley of the Amazon. vol. I. Washington, Taylor \& Mauri. $414 \mathrm{p}$.

Lawrence, J.F. and A. F. Newton, Jr. 1995. Families and subfamilies of Coleoptera (with selected genera, notes, references and data on family-group names). In J. Pakaluk and S.A. Slipinski (eds.). Biology, phylogeny, and classification of Coleoptera: Papers Celebrating the $80^{\text {th }}$ Birthday of Roy A. Crowson. Pp. 779-1092. Warszawa: Muzeum i Instytut Zoologii PAN, v. 2, vi+559-1092 pp.

Lawrence, J.F;; A.M. Hastings; M.J. Dallwitz; T.A. Paine and E.J. Zucher. 1999. Beetles of the world: a key and information system for families and subfamilies. Version 1.0 for MS-Windows. CSIRO Publishing, Melbourne, CD-Rom \& user manual.

Leng, C.W. and A.J. Mutchler. 1922. The Lycidae, Lampyridae and Cantharidae (Telephoridae) of the West Indies. Bulletin of the American Museum of Natural History 46: 413-499.

Linsley, E.G., T. Eisner and A.B. Klots. 1961. Mimetic assemblage of sibling species of lycid beetles. Evolution 15: 15-29.

Marshall, G.A.K and E.B. Poulton. 1902. Five years' observations and experiments (1896-1901) on the bionomics of South African insects, chiefly directed to the investigation of mimicry and warning colours. Transactions of the Entomological Society of London 287-697.

Moore, B.P. and W.V. Brown. 1981. Identification of warning odour components, bitter principles and antifeedants in an aposematic beetle: Metriorrhyncus rhipidius (Coleoptera: Lycidae). Insect Biochemistry 11: 493-499.

Nascimento, E.A. and M. Bocakova. 2009. A revision of the genus Lycomorphon (Coleoptera: Lycidae). Zootaxa 2132: 40-52.

Nascimento, E.A. and M. Bocakova. 2010a. Review of the Neotropical genus Cartagonum (Coleoptera: Lycidae). The Canadian Entomologist 142: 120-127.

Nascimento, E.A. and M. Bocakova. 2010b. A new genus of net-winged beetles from Neotropical Region (Coleoptera:Lycidae). Annales de la Société Entomologique de France 46: 449-452.

Nascimento, E.A. and M. Bocakova. 2012a. A new species of Picomicrolycus (Coleoptera: Lycidae), first record from South America and a key to species. Annales Zoologici 62: 267-271.

Nascimento, E.A. and M. Bocakova. 2012b. Nomenclatural changes and redescriptions in Plateros Bourgeois, 1879 (Coleoptera: Lycidae) from Neotropical region. Zootaxa 3487: 77-84.

Nascimento, E.A. and Del-Claro, K. 2010. Aposematismo e mimetismo em insetos da Mata Santa Tereza, p. 161-173. In C.M. Polegatto. A fauna de insetos da Mata Santa Tereza - Estação Ecológica de Santa TerezaSP. Ribeirão Preto: São Francisco Gráfica e Editora Ltda. 173 p.

Pic, M. 1929. Nouveautés diverses. Melanges exotico-entomologiques 53: 1-36.

Pic, M. 1949. Coléoptères du globe. L'Echange 516: 5-8.

Shelford, R.W.C. 1902. Observations on some mimetic insects and spiders from Borneo and Singapore. Proceedings of the Zoological Society of London 2: 230-284

Wallace, A.R. 1867. Mimicry and other protective resemblances among animals. Westminster and Foreign Quarterly Review 32: 1-43.

Zaragoza-Caballero, S. 1999. Cantharoidea (Coleoptera) de Mexico. III El género Plateros Bourgeois (Lycidae: Erotinae: Platerodini). Acta Zoológica Mexicana (nueva serie) 78: 1-71.

RECEIVED: July 2010

ACCEPTED: January 2013

Published ONLINE: April 2013

EDITORIAL RESPONSIBILITY: Ana Lúcia Tourinho 


\section{The current status of knowledge on Lycidae Laporte, 1836 from Brazil (Insecta: Coleoptera)}

Elynton Alves do Nascimento

Universidade Estadual do Centro-Oeste, Departamento de Engenharia Ambiental. PR 153, Km 7, Riozinho,. CEP 84500-000. Irati, PR, Brazil.

E-mail: elynton@yahoo.com.

\section{ERRATUM}

PAge 324, within TABLE 1:

Macrolygistopterus elegans Bourgeois, 1880, M. gounellei Bourgeois, 1886 and M. goyasensis Pic, 1923, should be Macrolygistopterus elegans (Bourgeois, 1880), M. gounellei (Bourgeois, 1886) and M. goyasensis (Pic, 1923).
We regret this error. 